Petkova, M., \& Aleksieva, M. (2022). Retrospective analysis of physical ability to 9-year-old students. Problems of Education in the Fourth Industrial Revolution Era. European Scientific e-Journal, 1 (16), 38-47. Ostrava: Tuculart Edition. Петкова, М., Алексиева, М. (2022). Ретроспективен анализ на физическа дееспособност на 9-годишни ученици. Problems of Education in the Fourth Industrial Revolution Era. European Scientific e-Journal, 1 (16), 38-47. Ostrava: Tuculart Edition. (на англ.)

DOI: $10.47451 /$ ped2021-12-002

The paper will be published in Crossref, ICI Copernicus, Academic Resource Index ResearchBib, J-Gate, ISI International Scientific Indexing, Zenodo, OpenAIRE, BASE, LORY, LUASA, ADL, eLibrary, and WebArchive databases.

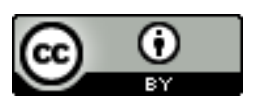

Miroslava Petkova, Associate Professor, PhD in Pedagogics, Theory and Methodology of Physical Education Department, "St. Cyril and St. Methodius" University of Veliko Tarnovo. Veliko Tarnovo, Bulgaria. ORCID: 0000-0001-9372-0530. Semantic Scholar: 48521708.

Milena Aleksieva, Professor, PhD in Pedagogics, Theory and Methodology of Physical Education Department, “St. Cyril and St. Methodius” University of Veliko Tarnovo. Veliko Tarnovo, Bulgaria. ORCID: 0000-0002-3537-3312. Semantic Scholar: 119254696.

\title{
Retrospective analysis of physical ability to 9-year-old students
}

Abstract: Physical capacity is not an inherent human quality. It is formed, developed and improved. It is achieved with a systematic and well-chosen training routine, which can lead to quantitative and qualitative changes in human capabilities when performing motor actions in a particular environment. The purpose of the present study is to analyze the results of the studied indicators of physical performance of 9 -year-old students for a 12-year period (2007-2019). The subjects are 9-year-old students, distributed in equal numbers - 50 in four groups, subjected to testing every 4 years during the school years 2007/2008, 2011/2012, $2015 / 2016$ and $2019 / 2020$. The survey was conducted at the beginning of each school year. The following methods are applied to solve the problems and achieve the goal of the experiment: 1 . Testing - includes 5 indicators for measuring physical capacity. 2. Mathematical-statistical methods - Variation, comparative and graphical analysis are used. The results obtained from the variation analysis are presented in tabular and graphical form. Tables 2-5 show the achievements after statistical processing of the data taken by means of tests carrying information about the physical capacity of 9 -year-old students during the 12 -year period, and Figures 1 and 2 show the variability of the studied indicators for different periods of time. Despite that, main conclusion of the study is that the physical capacity of 9-year-old students in 2019 is significantly improving. The tendency to observe a sedentary lifestyle, obesity and reduced physical activity in students is refuted by the present experiment. With regard to the first two indicators characterizing the explosive power of the lower and upper limbs, it can be summarized that in 2019 the average values in the test "Long jump from a place with two legs" have significantly increased, and in the indicator "Throwing a solid ball", the results have significantly decreased. For the other three indicators, determining the speed, endurance and flexibility of the surveyed students, it is found that the average values in 2019 are much better in comparison to those of the surveyed students in preceding periods. Research shows that the four samples for the period 2007-2019 are relatively homogeneous in all indicators of physical capacity.

Keywords: students, physical education, physical capacity, physical qualities. 
Мирослава Петкова, Аоцент, Аоктор, Теория и методика на физическото възпитание, Великотьрновски университет “Св. св. Кирил и Методий”, Велико Търново, България. ORCID: 0000-0001-9372-0530. Semantic Scholar: 48521708.

Мияена Алексиева, професор, Аоктор, Теория и методика на физическото възпитание, Великотьрновски университет “Св. св. Кирил и Методий”, Велико Търново, Бъцгария. ORCID: 0000-0002-3537-3312. Semantic Scholar: 119254696.

\section{Ретроспективен анализ на физическа дееспособност на 9-годишни ученици}

Абстракт: Физическата дееспособност се формира, развива и усъвършенства. Постига се със систематични и добре подбрани тренировъчни методи, които могат Аа АовеАат Ао количествени и качествени промени в човешките възможности при извършване на Авигателни действия в конкретна среда. Целта на настоящото изследване е Аа се анализират констатираните резултати от изследваните показатели за физическа дееспособност на 9-годишни ученици за 12-годишен период от време (20072019 г.). Учениците са 9-годишни ученици, разпределени на равен брой - 50 в четири групи, подложени на тестване на всеки 4 години през учебните 2007/2008, 2011/2012, 2015/2016 и 2019/2020. Проучването се провежАаше в началото на всяка учебна година. За решаване на задачите и постигане на целта на експеримента се прилагат следните методи: 1. Тестване - включва 5 показателя за измерване на физическата дееспособност. 2. Математико-статистически методи Използват се вариационен, сравнителен и графичен анализ. Резултатите, получени от вариационния анализ, са представени в табличен и графичен виА. В таблици от 2 до 5 са показани постиженията след статистическа обработка на Аанните, снети чрез тестове, носещи информация за физическата Аееспособност на 9-годишните ученици през 12-годишния период, а на фигури 1 и 2 е показана променливостта на изследваните показатели за различни периоди от време. Основното заключение от анализа на резултатите е, че физическата дееспособност на 9-годишните ученици през 2019 г. значително се подобрява. Тенденцията, че се наблюдава заседнац начин на живот, затлъстяване и намалена Авигателна активност при учениците, се опровергава от настоящия експеримент. По отношение на пьрвите Ава показателя, характеризиращи взривната сила на долните и горните крайници, може Аа се обобщи, че през 2019 г. средните стойности от теста „Скок на АъАжина от място с Ава крака“ са се увеличили значително, а при показателя „Хвърляне на пльтна топка“ резултатите значително намаляват. За останалите три показателя, определящи бързината, издръжливостта и гъвкавостта на изследваните ученици, се установява, че средните стойности през 2019 г. са много поАобри в сравнение с тези на учениците от предходните периоди. Изследванията показват, че четирите извадки за периода 2007-2019 г. са относително хомогенни по всички показатели за физическа Аееспособност.

Ключови думи: ученици, физическо възпитание, физическа дееспособност, физически качества.

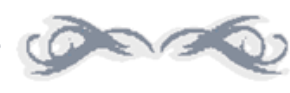

\section{Introduction}

The development of society is characterized by a pronounced offensive strategy for mastering nature and its subordination to human needs. At the heart of this process is the desire to minimize the physical efforts of people (National Strategy for the Development of Physical Education and Sports in the 
Republic of Bulgaria 2011-2020). The reduction of motor activity while the neuro-sensory load is significantly increased, causes irreparable damage to the activity of autonomic and motor functions.

They most significantly affect the physical capacity of students.

In the present conditions for physical education and sports in school, along with educational, motor, didactic and rehabilitation tasks, which as a subject it must accomplish, it is increasingly necessary to create conditions for diversification, expansion and enrichment of resources and methods in mastering the curriculum content tailored to the age of the trainees (Aleksieva \& Petkova, 2018:5).

In sports literature there are different interpretations of the concept of physical capacity. Depending on the individual approach of the different authors to the problem various definitions of the concept of its content can be traced, as well as terminological diversity of its definition physical fitness, physical performance, physical preparedness and more (Aleksieva, 2006:17).

Physical abilities can be called motor if they are based on the central neuro-regulatory mechanism for movement control, and psychomotor - when it comes to distinguishing the qualitative feature of motor action from the position of mental factors (Petkova \& Aleksieva, 2015). In this sense, physical capacity is not an inherent human quality. It is formed, developed and improved. It is achieved with a systematic and well-chosen training regime, which can lead to quantitative and qualitative changes in human capabilities when performing motor actions in a certain environment (Aleksieva, 2010:69).

According to A. Tsurova: "physical capacity is an inherent state of the human organism, characterised with a certain level of motor response, reached as a result of a functional adaptation to various biosocial influences. It plays a role in the physical qualities and motor skills, when performing particular motor tasks and can be developed and mastered." (Tsurova, 2019:9)

T. Tsankov points out that "the development of motor skills does not proceed evenly, but instead has periods when certain motor abilities develop rapidly, followed by periods of gradual development or stagnation. A crucial period is the phase of the sensory period when stimulation is need in order for a result to be achieved." (Tsankov, 2020:68)

The knowledge of the sensitive periods of the students in elementary school by the sports pedagogues helps increase the efficiency of the educational-training process, aimed at the development of the individual motor qualities by including appropriate means and methods (Denev, 2018:39).

The functional and motor components relevant to the particular quality develop the most effectively during the sensitive periods (Borukova, 2018).

These facts provoke our interest in the topic, which led to motivation for retrospective analysis of the physical capacity of 9-year-old students who were in fourth grade in the school years 2007/2008, 2011/2012, 2015/2016 and 2019/2020 - four groups for a period of twelve years.

The purpose of the present study is to analyze the results of the studied indicators of physical performance of 9-year-old students for a 12-year period (2007-2019).

The tasks arising from this goal are the following: 
1. To study the sports literature and to analyze the indicators which show the physical capacity of the students of the studied age.

2. To establish the level of the examined indicators in terms of physical capacity in 9-year-old students.

3. To compare the established values for the four surveyed sets.

4. To summarize and draw conclusions from the study.

\section{Methodology}

The study subject are the indicators of physical capacity of 9-year-old students.

The study object is the training in physical education and sports at elementary school.

The subjects are 9-year-old students, distributed in equal numbers - 50 in four groups, subjected to testing every 4 years during the school years 2007/2008, 2011/2012, 2015/2016 and 2019/2020. The four groups are from different schools in the town of Veliko Tarnovo - the ones studied in 2007 are from "Emilian Stanev" High School, in 2011 - from "Vela Blagoeva” High School, in 2015 - from "P.R. Slaveykov" Primary School and in 2019 - from "Dimitar Blagoev" Primary School. The survey was conducted at the beginning of each school year.

The following methods are applied to solve the problems and achieve the goal of the experiment:

1. Testing - includes 5 indicators for measuring physical capacity (Table 1).

2. Mathematical-statistical methods - Variation, comparative and graphical analysis are used. The obtained results were processed with a standard statistical program SPSS 21.

\section{Results}

The results obtained from the variation analysis are presented in tabular and graphical form. Tables 2-5 show the achievements after statistical processing of the data taken by means of tests carrying information about the physical capacity of 9 -year-old students during the 12 -year period, and Figures 1 and 2 show the variability of the studied indicators for different periods of time.

The explosive force of the lower limbs is established by the indicator "Long jump from a place with two legs". There is a similarity in the average values of the studied groups in 2007 and 2011, as well as those in 2015 and 2019. It turns out that for the 12-year period the 9-year-old students increased their average values by $13.17 \mathrm{~cm}$.

The values of the coefficient of variation $\mathrm{V}$ range between $11.41 \%$ in $2007,10.72 \%$ in 2011 , $14.30 \%$ in 2015 and between $5.28 \%$ in 2019. Therefore, all four surveyed sets are acceptably homogeneous in terms of the explosive force of the lower limbs with a tendency to reduce variability in 2019 (tab. 2-5 and fig. 1-2).

The explosive force of the upper limbs is examined by means of the "Throwing a solid ball" test. The data of the average values of the studied groups show a decrease in the results on this indicator. In the period 2007-2015 the average values are almost similar - $498.0 \mathrm{~cm}$ and $485.0 \mathrm{~cm}$, for 2015 $457.05 \mathrm{~cm}$, and in 2019 they significantly decreased by $114.17 \mathrm{~cm}$ - respectively $383.83 \mathrm{~cm}$. 
With regard to variability, the acceptable homogeneity is preserved in the four studied groups regarding this indicator (from $11.59 \%$ to $14.66 \%$ ), which characterizes the speed-power qualities of the students (tab. 2-5 and fig. 1-2).

To monitor the dynamics of speed development, the test "Running $50 \mathrm{~m}$ " was applied (tab. 2-5 and fig. 1-2). It is established that the average values of this indicator in 2007 and 2011 are similar, then in 2015 they decreased, and in 2019 decreased significantly by $-2.13 \mathrm{~s}$.

Judging by the variation $\mathrm{V}$ coefficient, the values of which range from $7.02 \%$ to $9.31 \%$, the studied groups are homogeneous with respect to this indicator.

To determine the level of endurance of 9-year-old students, the traditional test was used "Running 200 m" (tab. 2-5 and fig. 1-2). In 2007 and 2011 the results of the average values are approximately the same, in 2015 they are lower - $46.53 \mathrm{~s}$ and in 2019, they significantly improved by $-8.1 \mathrm{~s}$.

All four groups studied are homogeneous with respect to this indicator, which is confirmed by the values of the variation coefficients (from $9.48 \%$ to $6.29 \%$ ).

The "Slope depth" indicator is informative about the state of the flexibility quality. It is well known that flexibility is genetically determined and individual for everyone, it is relatively easy to train, but it is also lost very quickly (Aleksieva \& Petkova, 2018:80).

Tables 2-5 show that in the period from 2007 to 2011 the average value for the indicator increased from $100.73 \mathrm{~cm}$ to $100.79 \mathrm{~cm}$, in 2015 it decreased to $99.53 \mathrm{~cm}$ and in 2019 increases significantly again, with a value of $103.90 \mathrm{~cm}$. The observed samples show homogeneity in terms of the variation coefficient of $<10 \%$, where the values vary from $8.07 \%$ to $5.42 \%$ (tab. 2-5 and fig. 1-2) (Petkova \& Aleksieva, 2015).

\section{Discussion}

Today it is even more apparent that the development ot society is characterized by pronounced bold strategy for mastering nature and its subordination to human need. The education system is a main factor which determines the development of the social environment and at the same time the functioning of an education system is a consequence of the social requirements. At the heart of this process is the desire to minimize the physical efforts of people at the expense of the factors which influence positively the heath of the adolescents.

Despite that, main conclusion of the study is that the physical capacity of 9-year-old students in 2019 is significantly improving. The tendency to observe a sedentary lifestyle, obesity and reduced physical activity in students is refuted by the present experiment.

\section{Conclusions}

1. With regard to the first two indicators characterizing the explosive power of the lower and upper limbs, it can be summarized that in 2019 the average values in the test "Long jump from a place with two legs" have significantly increased, and in the indicator "Throwing a solid ball", the results have significantly decreased. 
2. For the other three indicators, determining the speed, endurance and flexibility of the surveyed students, it is found that the average values in 2019 are much better in comparison to those of the surveyed students in preceding periods.

3. Research shows that the four samples for the period 2007-2019 are relatively homogeneous in all indicators of physical capacity.

\section{Recommendations}

Prioritization of the development of the physical qualities of the upper and lower limb in the elementary stage of the basic educational system.

\section{References:}

Aleksieva, M. (2006). Establishing the current physical capacity of third grade students. Physical Education in Our Time. Collection of scientific articles, 17-24. Veliko Tarnovo: Boyka.

Aleksieva, M. (2010). The game approach in the training of mini-basketball. Mr. Sports and Science, 6, 69-75. Sofia.

Aleksieva, M., \& Petkova, M. (2018). The game approach in basketball training (Second revised and supplemented edition). Veliko Tarnovo: I\&B.

Borukova, M. (2018). Sports preparedness control of 13-14-year-old basketball players. Sofia: BOLID-INS

Denev, St. (2018). Football at school - training options. Veliko Tarnovo: I\&B.

National Strategy for Development of Physical Education and Sports in the Republic of Bulgaria 2011-2020.

Petkova, M. (2013). Optimization of physical development, physical capacity and mental qualities in students from the initial stage of basic education. Veliko Tarnovo: University of Veliko Tarnovo "St. Cyril and Methodius" COBISS.BG-ID - 1279088356.

Petkova, M., \& Aleksieva, M. (2015). Establishing the level of physical capacity of 7-, 8- and 9-yearold students after the applied game approach. Journal of Sport and Science, 5, 186-194. Ed. Stanka Videnova et al.

Tsankov, T. (2020). Multiyear training of female basketball players. Sofia: Nice AN Ltd.

Tsurova, A. (2019) Influence of different motor activities on the physical capacity of university students. Sofia: BOLID-INS. 


\section{Appendix}

Table 1. Description of the tests

\begin{tabular}{|c|c|c|c|c|}
\hline № & Indicators & $\begin{array}{c}\text { Measure } \\
\text { units }\end{array}$ & $\begin{array}{c}\text { Accuracy of } \\
\text { measurement }\end{array}$ & $\begin{array}{c}\text { Direction of } \\
\text { growth }\end{array}$ \\
\hline 1. & $\begin{array}{c}\text { Long jump from a place } \\
\text { with two legs }\end{array}$ & $\mathrm{cm}$ & 1 & + \\
\hline 2. & Throwing a solid ball & $\mathrm{cm}$ & 0,1 & + \\
\hline 3. & Running $50 \mathrm{~m}$ & $\mathrm{~s}$ & 0,1 & - \\
\hline 4. & Running $200 \mathrm{~m}$ & $\mathrm{~s}$ & 0,1 & - \\
\hline 5. & Depth of slope & $\mathrm{cm}$ & 1 & + \\
\hline
\end{tabular}

Table 2. Results of the variational analysis of the indicators showing the physical capacity of the studied in 2007 - at the beginning

\begin{tabular}{|c|c|c|c|c|}
\hline \multicolumn{2}{|c|}{ indicators } & X & S & V \\
\cline { 1 - 2 } № & name & & & \\
\hline $\mathbf{1 .}$ & Long jump from a place with two legs (cm) & 121.73 & 13.89 & 11.41 \\
\hline $\mathbf{2 .}$ & Throwing a solid ball (cm) & 498.0 & 0.73 & 14.66 \\
\hline $\mathbf{3 .}$ & $\mathbf{5 0} \mathbf{m}$ running (s) & 10.40 & 0.73 & 7.02 \\
\hline $\mathbf{4 .}$ & $\mathbf{2 0 0}$ m running (s) & 51.27 & 4.32 & 8.43 \\
\hline $\mathbf{5 .}$ & Slope depth (cm) & 100.73 & 7.18 & 7.13 \\
\hline
\end{tabular}

Table 3. Results of the variational analysis of the indicators informing about the physical capacity of the studied in 2011 - at the beginning

\begin{tabular}{|c|c|c|c|c|}
\hline \multicolumn{2}{|c|}{ indicators } & X & S & V \\
\cline { 1 - 2 } № & name & & & \\
\hline 1. & Long jump from a place with two legs (cm) & 120.71 & 12.94 & 10.72 \\
\hline 2. & Throwing a solid ball (cm) & 485.0 & 0.61 & 12.58 \\
\hline $\mathbf{3 .}$ & $\mathbf{5 0 ~ m ~ r u n n i n g ~ ( s ) ~}$ & 10.23 & 0.72 & 7.04 \\
\hline $\mathbf{4 .}$ & $\mathbf{2 0 0} \mathbf{m}$ running (s) & 51.35 & 3.23 & 6.29 \\
\hline $\mathbf{5 .}$ & Slope depth $(\mathbf{c m})$ & 100.79 & 7.15 & 7.09 \\
\hline
\end{tabular}


Table 4. Results of the variational analysis of the indicators showing the physical capacity of the studied in 2015 - at the beginning

\begin{tabular}{|c|c|c|c|c|}
\hline \multicolumn{2}{|c|}{ indicators } & X & S & V \\
\cline { 1 - 2 } № & name & & & \\
\hline 1. & Long jump from a place with two legs (cm) & 133.53 & 19.09 & 14.30 \\
\hline 2. & Throwing a solid ball (cm) & 457.05 & 59.40 & 12.99 \\
\hline 3. & 50 m running (s) & 11.12 & 0.99 & 8.90 \\
\hline 4. & 200 m running (s) & 46.53 & 4.41 & 9.48 \\
\hline 5. & Slope depth (cm) & 99.53 & 8.03 & 8.07 \\
\hline
\end{tabular}

Table 5. Results of the variational analysis of the indicators showing the physical capacity of the studied in 2019 - at the beginning

\begin{tabular}{|c|c|c|c|c|}
\hline \multicolumn{2}{|c|}{ indicators } & X & S & V \\
\cline { 1 - 2 } № & name & & & \\
\hline 1. & Long jump from a place with two legs (cm) & 134.90 & 7.12 & 5.28 \\
\hline $\mathbf{2 .}$ & Throwing a solid ball (cm) & 383.83 & 44.48 & 11.59 \\
\hline $\mathbf{3 .}$ & $\mathbf{5 0} \mathbf{m}$ running (s) & 8.27 & 0.77 & 9.31 \\
\hline 4. & 200 m running (s) & 43.17 & 2.94 & 6.81 \\
\hline $\mathbf{5 .}$ & Slope depth (cm) & 103.90 & 5.63 & 5.42 \\
\hline
\end{tabular}

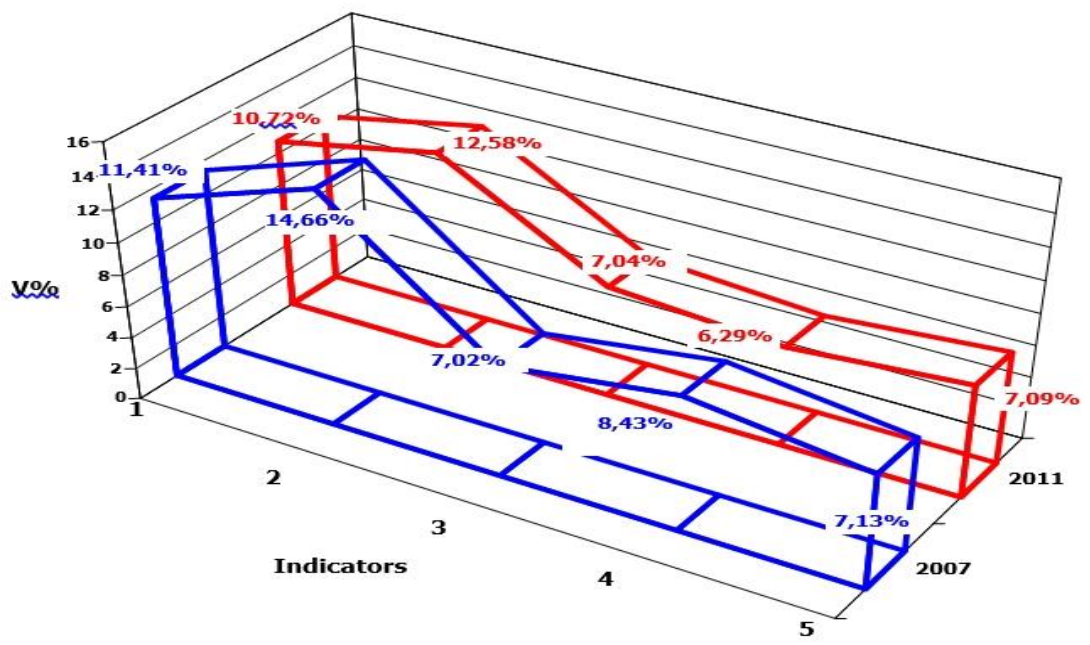

Figure 1. Dispersion of indicators of physical capacity at the beginning of the study 


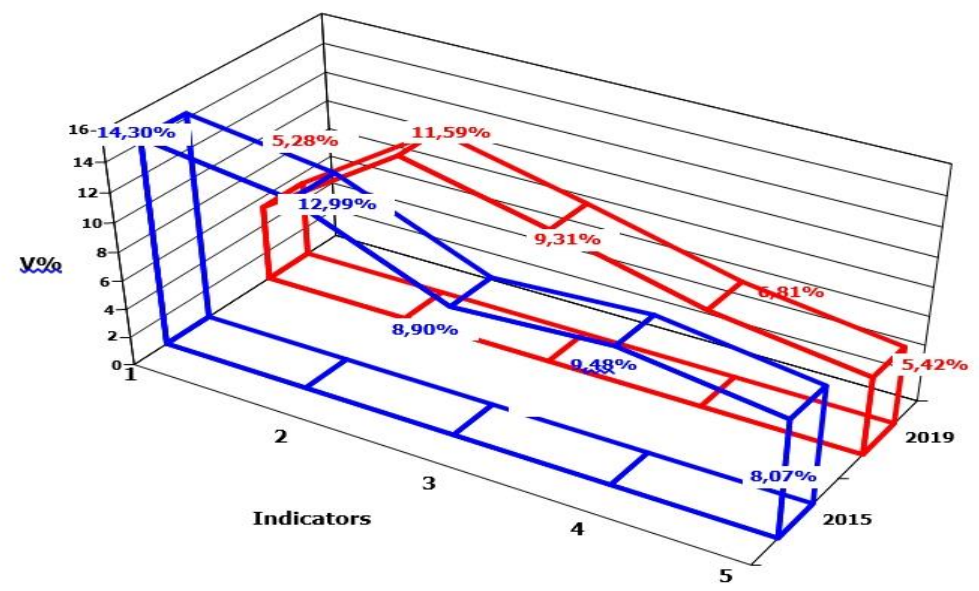

Figure 2. Dispersion of signs of physical capacity at the beginning of the study 